\title{
Porophyllum woodii (Compositae: Heliantheae: Pectidinae), a new species from Prov. Burnet O'Connor, Departamento de Tarija, Bolivia
}

\section{J. Nicholas Hind ${ }^{1}$}

Summary. Porophyllum woodii (Compositae: Heliantheae: Pectidinae), a new species from Prov. Burnet O’Connor, Departamento de Tarija, Bolivia, is described and illustrated. This new species is distinctive in that it is apparently the largest shrubby species in South America, with flowering plants up to $1.5 \mathrm{~m}$ tall, possessing alternate, longlinear, spreading to recurved leaves, solitary terminal capitula with phyllaries with two more-or-less even rows of linear glands, and about 40 - 45 florets per capitulum.

Key Words. Asteraceae, Bosque Seco Chiquitania, Dry Chiquitano Forest.

\section{Introduction}

During February and March of 2016, the author, accompanied by J. R. I. Wood and Gloria Gutierrez (our Bolivian counterpart and Curator of the herbarium of Santa Cruz Botanical Garden), undertook fieldwork as a scouting exercise for a project examining the inselberg flora of the Departamento de Santa Cruz, Bolivia, part-funded by the Bentham-Moxon Trust. By way of covering current research interests of John Wood, and to provide me with an insight into the flora of the Departamento de Tarija, we also took an excursion south, to the area of Entre Ríos, a region dominated by the highly undulating landscape of the Andean foothills and the Dry Chiquitano Forest (Bosque Seco Chiquitania).

It was during the latter excursion, at the end of February, that we were passing through the Provincia Burnet O'Connor between Palos Blancos and Entre Ríos, and both of us simultaneously spotted a small colony of a large grey-green linear-leaved shrub on the roadside slopes (Fig. 1, Map 1). This colony proved to be a species of Porophyllum Guett. (Compositae: Heliantheae: Pectidinae), and specifically sect. Porophyllum, which constitutes the South American (and a few North American) species of the genus. However, a study of the material, in Santa Cruz and in Kew, indicated that Johnson's key (Johnson 1969) failed to identify the species, beyond belonging to sect. Porophyllum. Keying out in the species under sect. Porophyllum led to the penultimate couplet and with a group of species that include the relatively widespread Mexican and Central American P. punctatum (Mill.) S.F.Blake, and the Mexican P. nutans B.L.Rob. \& Greenm. and P. viridiflorum (Kunth) DC.
Porophyllum belongs to a distinctive group of genera (see Hind 2000), at times placed in their own tribe, the Tageteae Rydb., but recognised here as belonging to the Heliantheae subtribe Pectidineae Less. (see Robinson 1981). Porophyllum is represented by monoecious or gynodioeceous, annual or perennial herbs, or moderately to densely branched suffrutices or shrubs, with opposite or alternate, sessile or petiolate, linear to ovate leaves with marginal pellucid glands, a strong aroma, but the leaves lacking the conspicuous basal cilia of other genera in the subtribe. The inflorescences are of solitary terminal capitula or few to several capitula in corymbose or paniculiform cymes. The capitula are discoid, ecalyculate, possess an involucre of connate, uniseriate, often conspicuously (at least when dry) gland-dotted phyllaries, and an epaleaceous receptacle. The florets are actinomorphic, although sometimes with conspicuously recurved upper corolla tubes, to slightly zygomorphic, with offwhite, yellowish, yellowish-green, brownish or deep purplish 5-lobed corollas, and cylindrical, fusiform black, setuliferous achenes, a conspicuous carpopodium, and with uni- or bi- seriate pappus of white, pale brown or somewhat reddish, capillary barbellate setae.

All the genera have a somewhat distinctive habit, invariably with characteristic aromatic (sometimes pungently so) oil glands on the leaves and phyllaries (Robinson 1996). Porophyllum is a genus of well over 30 species (c.f. Johnson 1969; Panero 2006), although Johnson's species concept, and the considerable additional collections now available from South America, will probably eventually see the total number of species exceeding 45 (see Hind 1995, 2000, 2002; Keil

\footnotetext{
Accepted for publication 31 July 2020. Published online 17 December 2020

1 Herbarium, Royal Botanic Gardens, Kew, Richmond, Surrey, TW9 3AE, UK. e-mail: n.hind@kew.org
} 


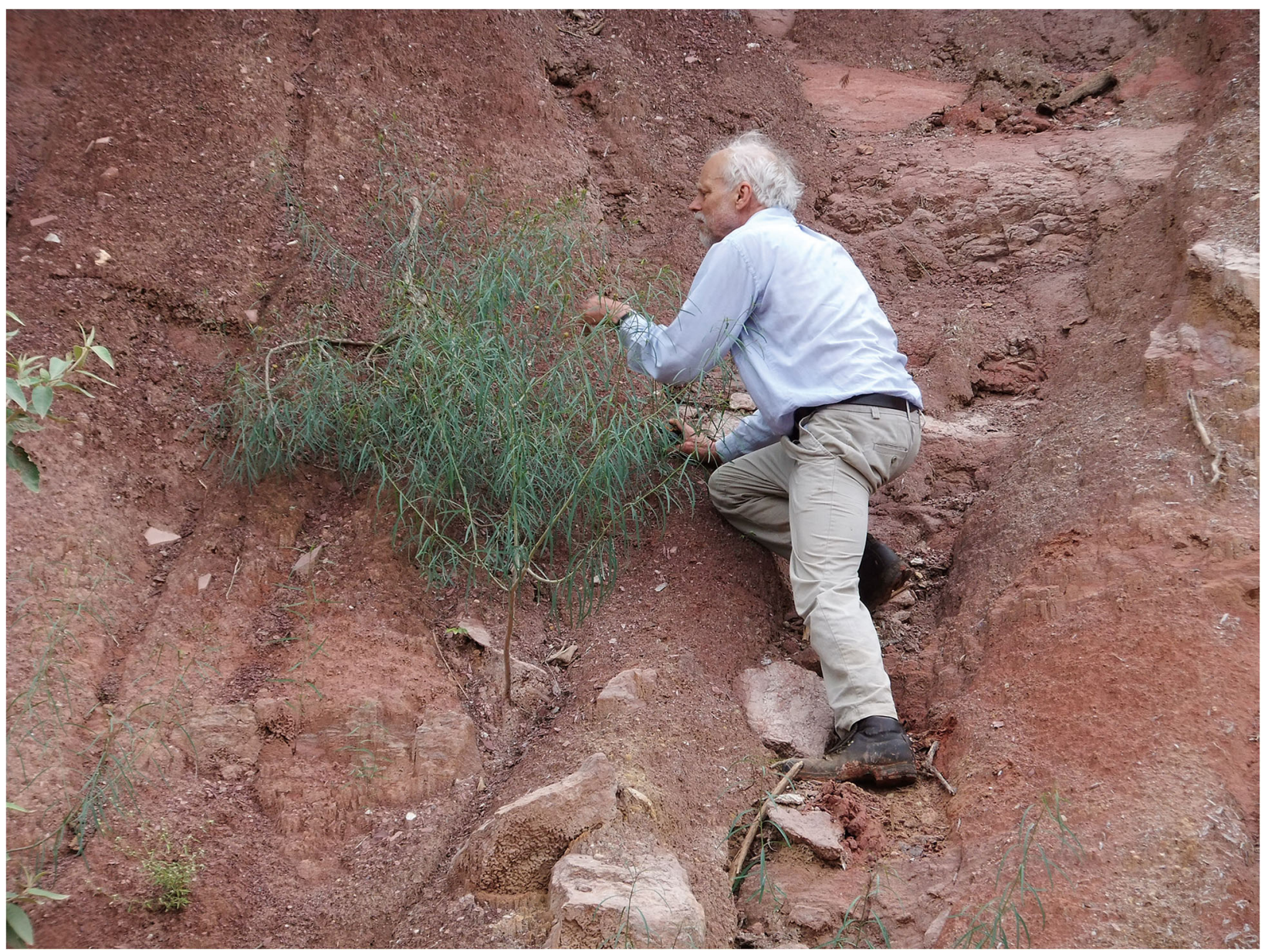

Fig. 1. John R. I. Wood collecting material of Porophyllum woodii on a steep slope of lateritic soil on the roadside between Palos Blancos and Entre Ríos, Dept. Tarija, Bolivia. PHOTO: (C) D. J. NICHOLAS HIND.

\& Morefield 1989; Turner 1983). Currently, in South America, seven species are recorded from Brazil (Nakajima 2010 - although one listed taxon, $P$. leiocarpum (Urb.) Rydb., is considered a synonym of $P$. ruderale (Jacq.) Cass., and with the addition of P. spathulatum C.R.Carneiro \& A.A.Schneid. described after Nakajima's original list, the total remains the same; Carneiro (2015), suggested nine, but there are several errors with invalid names, authorities and orthographies to use this as a reliable source), six from Argentina (Petenatti 2015), and only one from Colombia (Avila et al. 2016), Ecuador (Robinson 2006) and Peru (Dillon \& Hensold 1993) - the widespread $P$. ruderale. The most species rich area currently recorded is Mexico (16 spp. - Villaseñor 2016; cf. 19 spp. - Turner 1996). Hind (2011), and Robinson (2014), have only recorded four species from Bolivia, but this figure falls far short of the number of species represented by Wood's collections from the country, and only one, P. obscurum (Spreng.) DC., a gynodioecious suffrutex with opposite leaves, is currently recorded from Tarija. This current paper is the first, working towards describing these undoubtedly new species, and this new shrubby species from Tarija is described below.

\section{Description}

Porophyllum woodii D.J.N.Hind, sp. nov. Type: Bolivia: Depto. Tarija: Prov. Burnet O'Connor. [On road between Palos Blancos and Entre Rios]. 21 ${ }^{\circ} 25^{\prime} 41.1^{\prime \prime S}$, 6359'87.6"W, 1112 m, 28 Feb. 2016, Wood et al. 28040 (holotype USZ, isotypes K, LPB).

http://www.ipni.org/urn:lsid:ipni.org:names:77213113-1

Relatively poorly branched, apparently monoecious, shrubs to $1-1.5 \mathrm{~m}$ tall, erect or ascending, assurgent, sometimes almost decumbent (on steep slopes). Stems c. $15 \mathrm{~mm}$ diam. at base, terete (in fresh material) to striate (in herbarium material, ribs yellowish green), leafless and fawn-coloured in lower $1 / 3$ to $1 / 2$ and conspicuously leafy in current year's growth and inflorescences from last-season's major branching nodes, usually appearing glabrous except for uppermost nodes which are sometimes sparsely pubescent; internodes c. $10-$ 


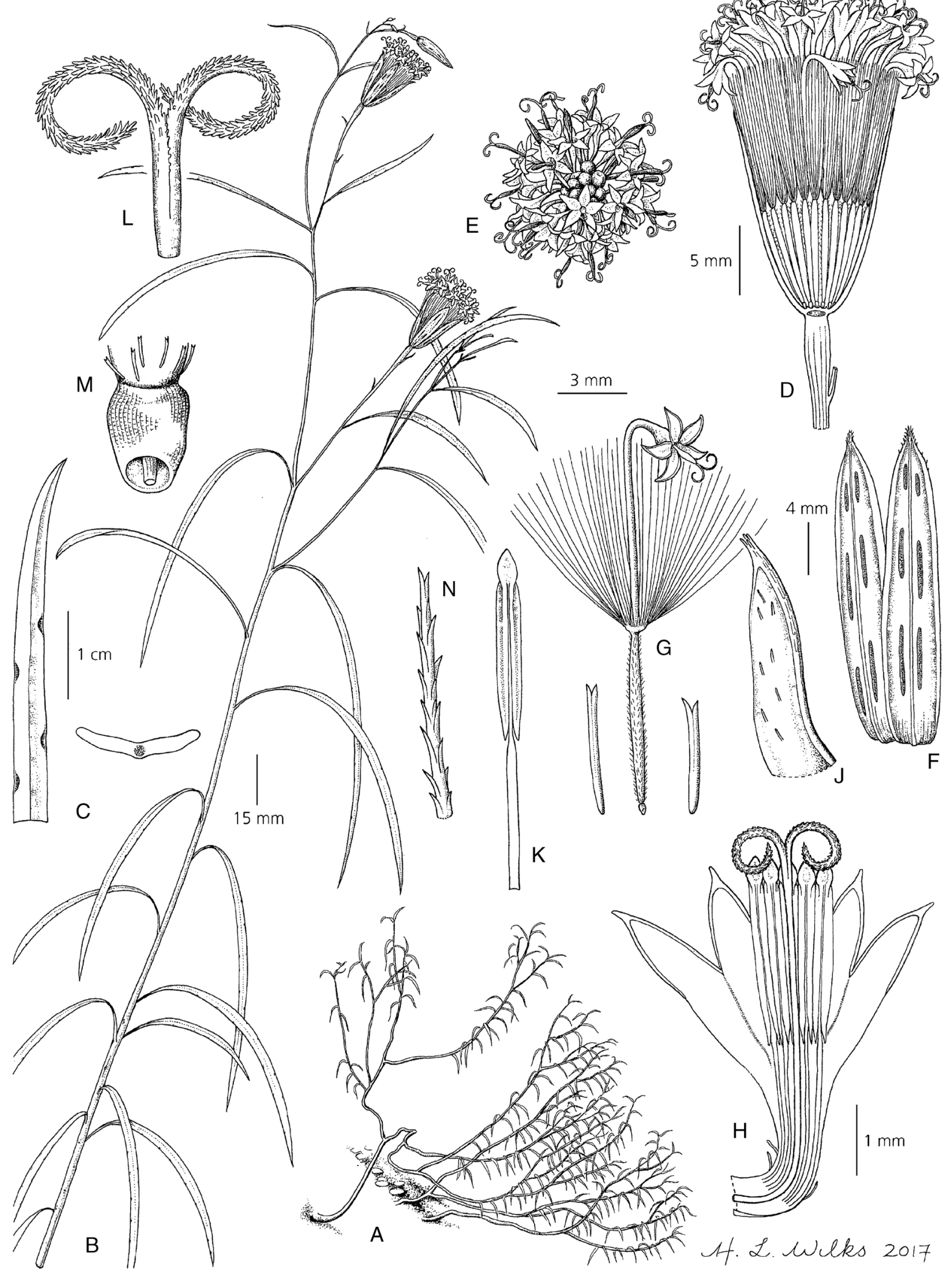

Fig. 2. Porophyllum woodii. A habit of flowering plants; B apex of flowering branch; C detail of leaf showing marginal glands and t.s. of a leaf; D I.s. capitulum; E capitulum viewed from above showing spreading outer floret corollas; F adjacent phyllaries; $\mathrm{G}$ floret with details of achene setulae; $\mathrm{H}$ l.s. upper portion of corolla to show attachment point of filaments; J side view of corolla lobe; $\mathrm{K}$ stamen; L style arms; M detail of carpopodium; N detail of apex of pappus seta. From Wood et al. 28040 (isotype, K). DRAWN BY HAZEL WILKS. 

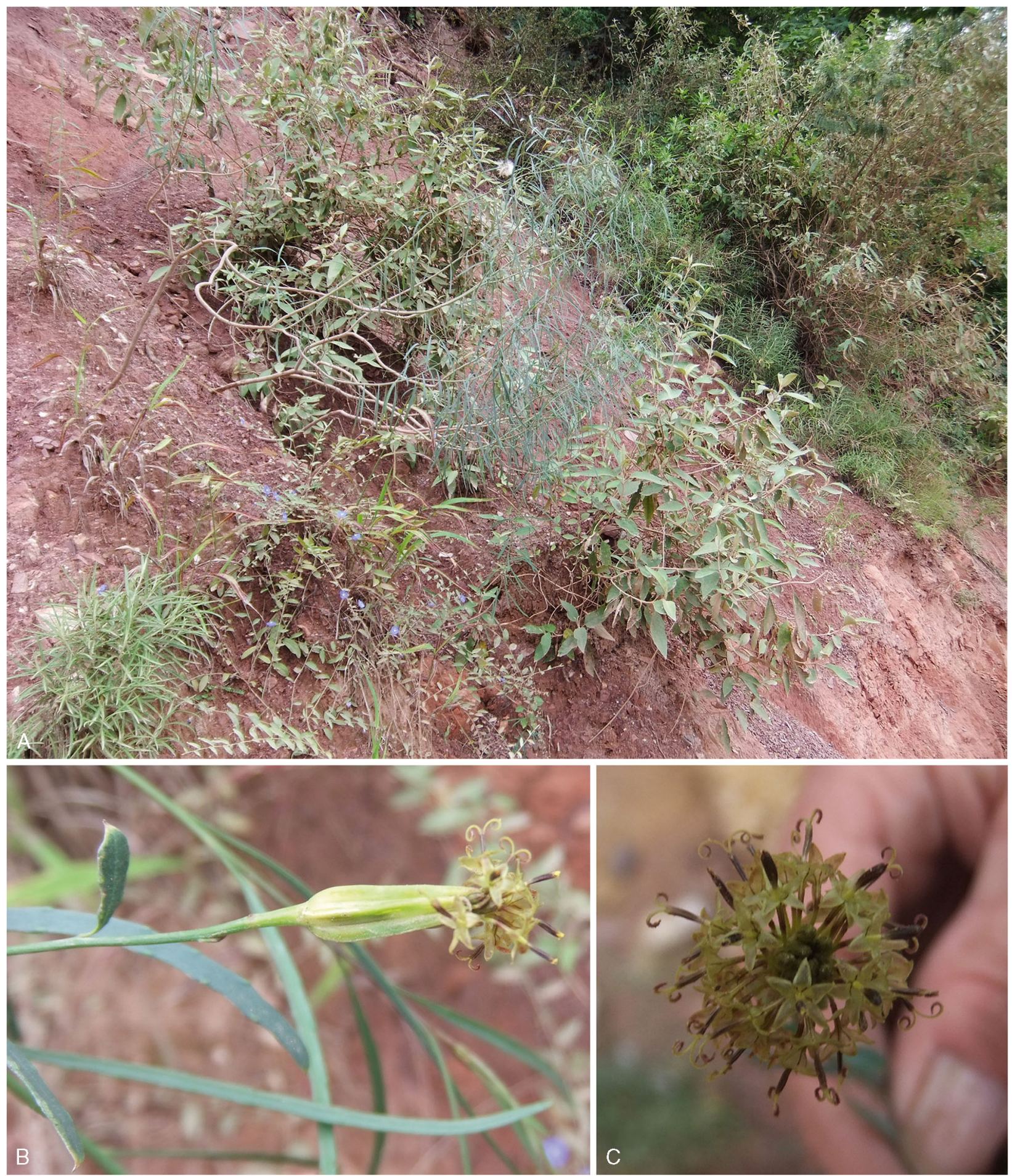

Fig. 3. A lateritic soil slopes of the type locality of Porohpyllum woodii, showing several plants with their characteristic ascending or assurgent branched stems, and almost dropping linear leaves; B a single-headed inflorescence of $P$. woodii, with the broad-linear leaves in the background showing the scarcely evident marginal glands; $C$ top view of a flowering capitulum of $P$. woodii showing the translucent corolla lobes with their dark venation from the sinuses between adjacent lobes joining to the purplish portion of corolla tube (indicating the attachment point of the anther filaments), the purplish anthers and coiled purplish-tipped style arms. ALL PHOTOS (C) D. J. NICHOLAS HIND. 


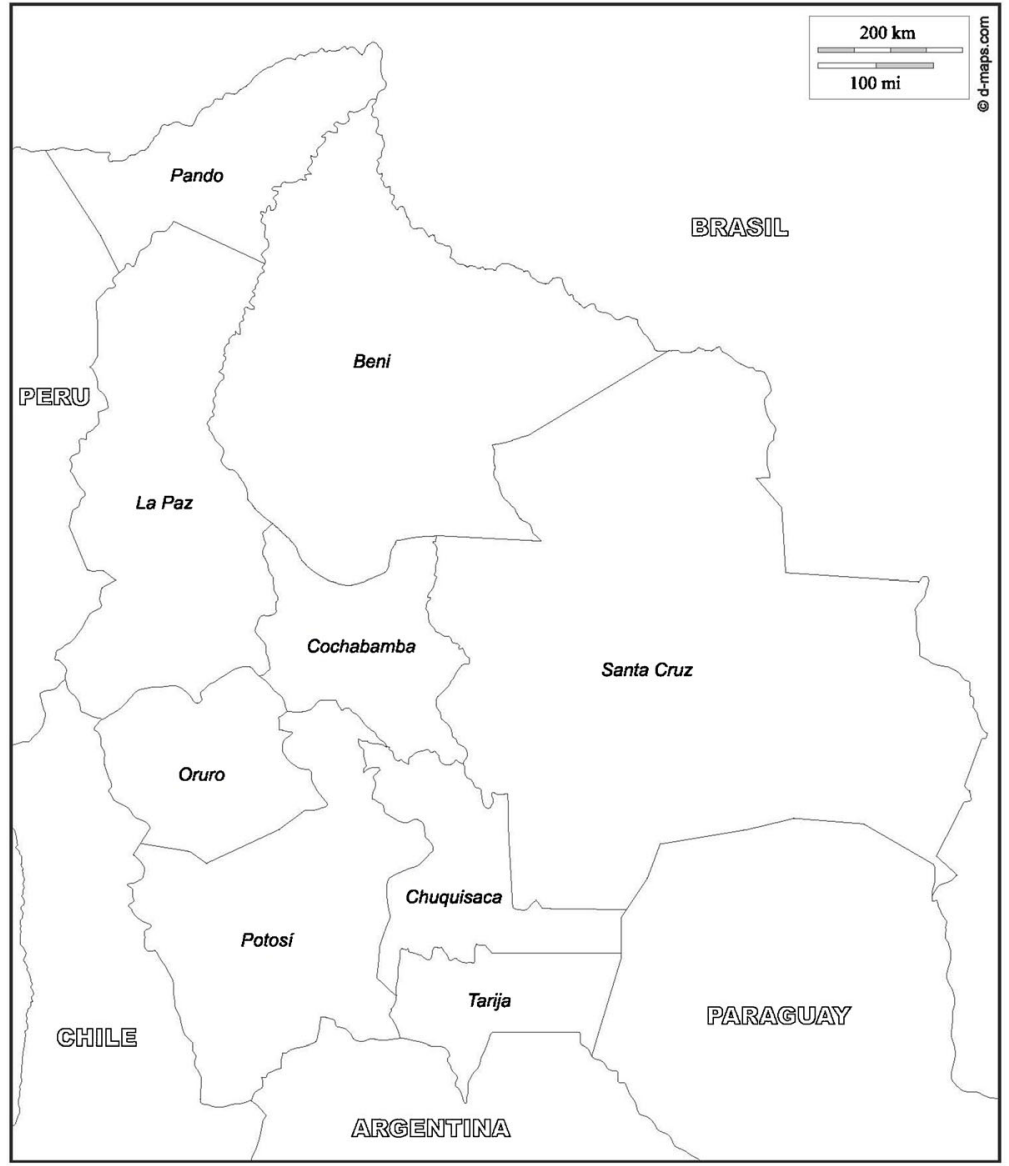

A

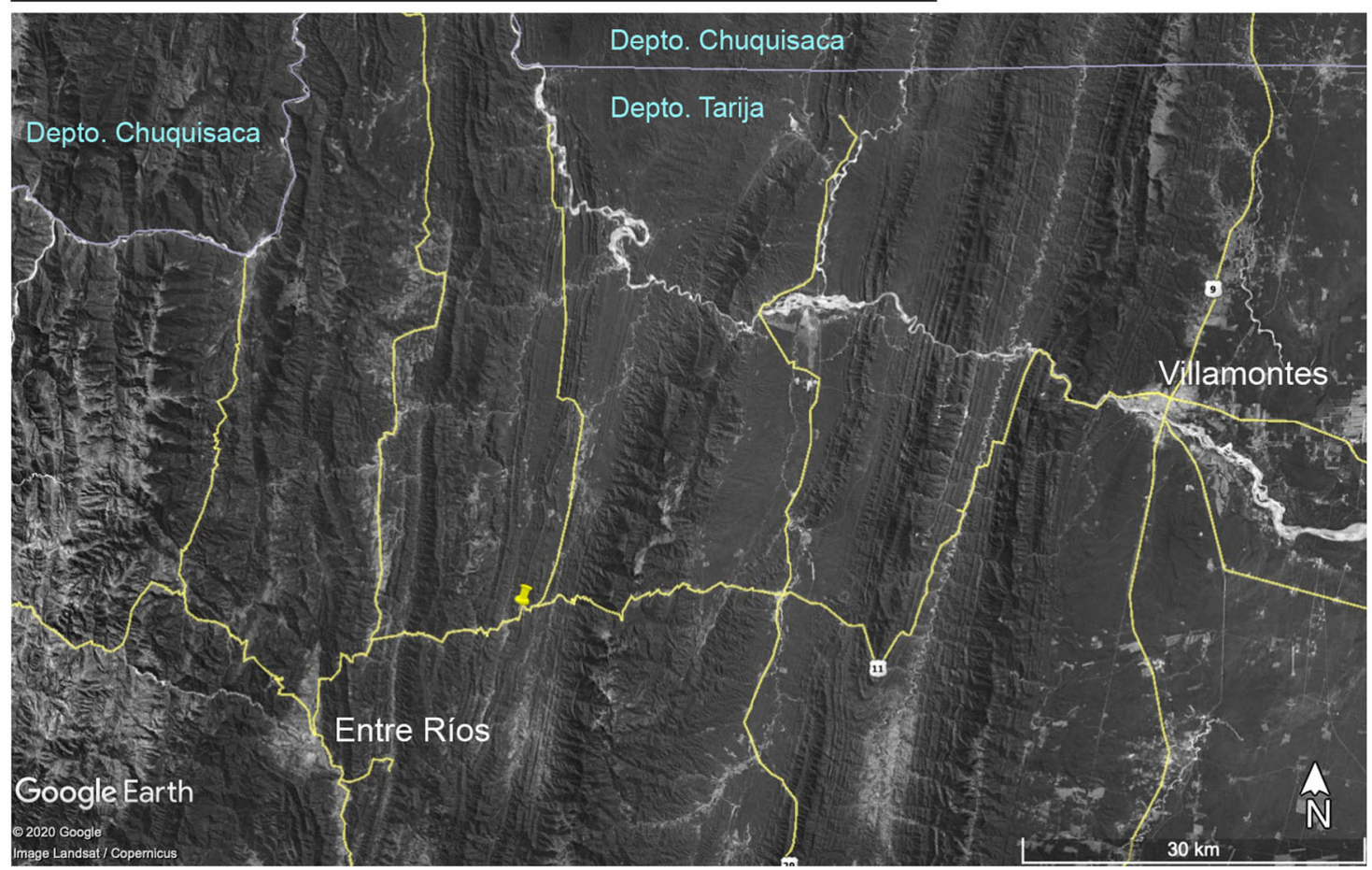

Map 1. A map of Bolivia. [inset image] B Google Earth Pro@ image indicating the location of the type locality of Porophyllum woodii, showing the undulating Andean foothills in Dept. Tarija, Bolivia, with the conspicuous Río Pilcomayo forming part of the border between Dept. Tarija and Depto. Chuquisaca in the top left of the inset. 
$25 \mathrm{~mm}$ long. Leaves alternate, sessile, linear, $50-100 \mathrm{~mm}$ long $\times$ c. $2-4 \mathrm{~mm}$ wide, usually spreading, to slightly recurved, subfleshy, concolorous and midrib often paler and yellowish-green) above and beneath (at least in herbarium material), margins entire, glands usually 7 or 8 per margin, margins slightly thicker and with scarce protuberances where glands occur and glands scarcely paler than lamina (conspicuous only in herbarium material as dark areas along margin or slightly submarginal), apices acute (tending to apiculate with a hardened discoloured point). Inflorescences of solitary terminal capitula, pedicels $2.5-5.5 \mathrm{~cm}$ long, scarcely inflated beneath involucre, usually solitary-bracted, bract 5 $35 \mathrm{~mm}$ long $\times 1-1.5 \mathrm{~mm}$ wide, leaf-like. Capitula homogamous and discoid, erect in bud and flower; involucre somewhat inflated in lower half and narrowing to apex when in flower; phyllaries 5, appearing connate (except for apical portion) in bud and early flowering, divided to base and reflexed at 'clock' stage at achene maturity prior to dispersal, carinate over midrib in bud (and distinctly ridged in herbarium material), $15 \mathrm{~mm}$ long $\times 2.5-3 \mathrm{~mm}$ wide, yellowish green, glands (3 or 4 pairs) in lines one on either side of midrib, ovate or linear to long-linear, $1-3.5 \mathrm{~mm}$ long, scarcely visible in fresh material, dark in herbarium material, alternate margins herbaceous and whitish and scarious, usually 1 margin entire (herbaceous margin) and other whitish and almost scarious, lacerate to ciliate (especially towards apex), apices acute, puberulent; receptacle scarcely convex, epaleaceous, glabrous. Florets (25 -) 40 - 45, hermaphrodite, all fertile; corollas dull yellow to yellowish-green (appearing light green in herbarium material), corolla tube c. $8 \mathrm{~mm}$ long (to base of crook) × c. $0.2 \mathrm{~mm}$ diam., 'crook tube' (to base of expanded funnelform throat) $\mathrm{c}$. $1.5 \mathrm{~mm}$ long, expanded crateriform base c. $1 \mathrm{~mm}$ long, base of corolla tube slightly flared, c. $0.4 \mathrm{~mm}$ diam., tube moderately to sparsely short-eglandular-pubescent throughout becoming sparsely pubescent towards crook bend and throat, tube usually conspicuously strongly recurved into a crook (especially majority of outer florets) and purplish towards base of upper tube at about insertion point of filaments, venation from base of sinus down to attachment point of filaments often dark (in herbarium material) and merging with purple base of throat and upper portion of corolla tube, corolla lobes 5 , c. $1.5 \mathrm{~mm}$ long $\times 0.5 \mathrm{~mm}$ wide, spreading and with a crateriform base to throat, eglandular and glabrous, appearing almost translucent (when viewed close up) and with scarcely purplish apices (when fresh); anther cylinder greyish to dark brown (when fresh, and somewhat pinkish brown in herbarium material), markedly exserted from corolla (often with anther collar visible out of throat), apical anther appendages triangular, slightly longer than wide, eglandular abaxially, apices acute, basal appendages tailed, anther collar scarcely conspicuous and contiguous with flattened filament, purplish; style yellowish-green at bifurcation and on style shaft above anther cylinder, style arms strongly recurved and coiled, apical portion purple and covered in sweeping hairs, hair apices acute. Achenes c. $7 \mathrm{~mm}$ long (immature), body black (cellular pattern of epidermis conspicuous under a microscope), moderately and conspicuously adpressed-setuliferous throughout, setulae of twin hairs, apices subequally short-divided (appearing like very short-pronged olive forks), apical cells acute, base of setulae conspicuously amber-coloured; carpopodium conspicuously asymmetric, c. $0.4 \mathrm{~mm}$ long, attachment point on one side, straw-coloured, to ambercoloured towards base of achene; pappus setae $8-10 \mathrm{~mm}$ long, capillary, spreading, barbellate, white but occasionally flecked purple (under a hand lens or microscope). Fig. 2, 3B, 3C.

RECOGNITION. Porophyllum woodii is unique in the genus as a tall, relatively poorly-branched shrub to c. $1.5 \mathrm{~m}$ tall, with alternate, long-linear spreading to recurved leaves, $7-10+\mathrm{cm}$ long, and solitary terminal erect capitula; phyllaries 5; florets (20 -) c. 40 - 45, corollas yellowish-green. Amongst the other perennial shrubby species in sect. Porophyllum it differs from P. punctatum in possessing long, sessile, linear entire-margined leaves (to $100 \mathrm{~mm}$ long $\times 2-4 \mathrm{~mm}$ wide) vs mostly opposite, petiolate oblong, ovate or elliptical sinuatemargined leaves $(10-40 \mathrm{~mm}$ long $\times 6-24 \mathrm{~mm}$ wide), and more florets ((25-) $40-45$ vs $15-30)$; differs from $P$. nutans which has mostly opposite, petiolate ovate to elliptical, sinuate-margined leaves (17 $29.5 \mathrm{~mm} \times 8.5-15 \mathrm{~mm}$ wide); and from $P$. viridiflorum which has mostly opposite, petiolate ovate to obovate, subentire- to sinuate- margined leaves $(<50 \mathrm{~mm}$ long $\times 36 \mathrm{~mm}$ wide $)$; both $P$. nutans and $P$. viridiflorum have about 20 florets per capitulum. DISTRIBUTION. Known only from the type collection in Depto. Tarija, Prov. Burnet O'Connor, Bolivia. Map 1B.

SPECIMEN EXAMINED. BOLIVIA. Depto. Tarija: Prov. Burnet O'Connor. [On road between Palos Blancos and Entre Ríos]. 21 ${ }^{\circ} 25^{\prime} 411^{\prime \prime S}, 63^{\circ} 59^{\prime} 876^{\prime \prime W}, 1112$ m, 28 Feb. 2016, Wood et al. 28040 (holotype USZ, isotypes K, LPB).

HABITAT/ECOLOGY. The type collection was made from a plant in small colony of about a dozen or so plants on a steep roadside slope, parts of which were devoid of vegetation, on a loose lateritic soil prone to slippage and water erosion. Higher on the slope Dry Chiquitano Forest (Bosque Seco Chiquitania) is the dominant vegetation type. Altitude \pm 1110 m. Figs 1 \& $3 \mathrm{~A}$.

PHENOLOGY. Material was in full flower in late February, and the presence of mature fruiting capitula, with the pappus fully expanded into a 'clock', indicated that it may flower from (late January or) early February until mid-March.

ETYMOLOGY. The specific epithet honours John R. I. Wood, who valiantly scaled up the steep roadside slope to collect material. 
CONSERVATION STATUS. Although known from the type locality, few other colonies were seen along the roadside in the immediate vicinity. The only clear danger to the type locality is the continued threat of road construction/ road widening which may destroy the roadside vegetation, along with any landslides that may occur, whether natural or manmade (should any new road be built on the hillside above the type locality); this could also be regarded as beneficial. The opening up of a new habitat is best suited for many Compositae that are well able to cope with competition in disturbed habitats once the pappus-dispersed achenes have landed, germinated, and the plants established on them. However, it is considered better to record the conservation status as DD (Data Deficient), awaiting further detailed fieldwork in the area to enable the population sizes and the area of occupancy to be assessed, together with that of any planned road construction/works.

\section{Acknowledgements}

The author would like to thank John Wood for his excellent company on the three excursions into the field in Bolivia in early 2016, and to the other two students, Maria [Rene] Arias and [Maria Luisa] Andrea Peñarrieta, who accompanied us, one on each of the other trips. Grateful thanks are also due to Hazel Wilks for the line drawing of the plant which has proven to be particularly fragile in the dry state, and; once again thanks to the Bentham-Moxon Trust in providing a substantial amount of funding for this trip. The valuable comments of two anonymous reviewers usefully improved the quality of the original script.

Open Access This article is licensed under a Creative Commons Attribution 4.0 International License, which permits use, sharing, adaptation, distribution and reproduction in any medium or format, as long as you give appropriate credit to the original author(s) and the source, provide a link to the Creative Commons licence, and indicate if changes were made. The images or other third party material in this article are included in the article's Creative Commons licence, unless indicated otherwise in a credit line to the material. If material is not included in the article's Creative Commons licence and your intended use is not permitted by statutory regulation or exceeds the permitted use, you will need to obtain permission directly from the copyright holder. To view a copy of this licence, visit http://creativecommons.org/ licenses/by/4.0/.

\section{References}

Avila, F., Funk, V. A., Diazgranados, M, Díaz-Piedrahítat, S., Vargas, O., Rodrígues-Cabeza, V., Aguilar-Cano, J. \& Holmes, W. C. (2016). Porophyllum. In: R. Bernal, S. R. Gradstein, \& M. Celis (eds), Catálogo de plantas y líquenes de Colombia. Vol. 1. Universidad Nacional de Colombia, Sede Bogotá.

Carneiro, C. R. (2015). Porophyllum in Flora do Brasil 2020 under construction. Jardim Botânico do Rio de Janeiro. Available at: http:/ / floradobrasil.jbrj.gov.br/ jabot/floradobrasil/FB16259. Accessed 2 June 2020.

Dillon, M. O. \& Hensold, N. (1993). Asteraceae. In: L. Brako \& J. L. Zarucchi (eds), Catalogue of the flowering plants and gymnosperms of Peru. Monogr. Syst. Bot. Missouri Bot. Gard. 45: 103 - 189. [Porophyllum: 167].

Hind, D. J. N. (1995). Compositae. In: B. L. Stannard (ed.), Flora of the Pico das Almas, Chapada Diamantina, Bahia, Brazil, pp. 175 - 278. Royal Botanic Gardens, Kew.

(2000). A new species of Porophyllum (Compositae: Heliantheae) from Argentina. Kew Bull. 55: 387 - 391. (2002). A new species of Porophyllum (Compositae: Heliantheae) from Bahia, Brazil. Kew Bull. 57: 705 709.

(2011). An annotated preliminary checklist of the Compositae of Bolivia. Vers. 2. [See www.kew.org/ science/tropamerica/boliviacompositae for the web version and www.kew.org/science/ tropamerica/boliviacompositae/checklist.pdf for the PDF file of the checklist].

Johnson, R. R. (1969). Monograph of the plant genus Porophyllum (Compositae: Helenieae). Univ. Kansas Sci. Bull. 48 (7): 225 - 267.

Keil, D. J. \& Morefield, J. D. (1989). Porophyllum pygmaeum (Asteraceae), a distinctive new species from Southern Nevada. Syst. Bot. 14 (4): 583 - 588.

Nakajima, J. M. (2010). Porophyllum. In: Organização R. C. Forrza et al., Catálogo de plantas e fungos do Brasil, pp. 732 - 733. Andrea Jakobsson Estúdio, \& Instituto de Pesquisas, Jardim Botânico do Rio de Janeiro.

Panero, J. L. [2006] (2007). Subtribe Pectidinae Less. Compositae. In: J. W. Kadereit \& C. Jeffrey (vol. eds), Flowering plants. Eudicots: Asterales (of K. Kubitzki (series ed.), The Families and Genera of Vascular Plants Vol. 8. pp. 423 - 430. SpringerVerlag, Berlin, Heidelberg, New York.

Petenatti, E. M. (2015). Porophyllum Guett. In: A. M. Anton \& F. O. Zuloaga (dirs), Flora Argentina: flora vascular de la República Argentina. Dicotyledonae, Asteraceae (S. E. Freire, vol. co-ord.). Vol. 7, part 2. Cichorieae, Helenieae a Mutisieae: pp. 109 - 114. Graficamente Ediciones, Córdoba (Argentina). 
Robinson, H. (1981). A revision of the tribal and subtribal limits of the Heliantheae (Asteraceae). Smithsonian Contr. Bot. 51 (1 - 4): 1 - 102.

(1996). Recent studies in the Heliantheae and Eupatorieae. In: D. J. N. Hind \& H. J. Beentje (eds), Compositae: Systematics. Proceedings of the International Compositae Conference, Kew, 1994 (D. J. N. Hind, Editor-in-Chief). 1: 627 - 653. Royal Botanic Gardens, Kew.

(2006). Porophyllum. In: G. Harling \& L. Andersson (eds), Flora of Ecuador, No. 77 (2): 190 (6). CompositaeHeliantheae, Part II: genera M - Z, pp. $69-74$. Botanical Institute, Göteborg University, Göteborg \& Section for Botany, Riksmuseum, Stockholm.

(2014). Porophyllum. In: P. M. Jørgensen, M. H. Nee \& S. G. Beck (eds), Catálogo de las plantas vasculares de Bolivia. Monogr. Syst. Bot. 127 (2 vols).
Turner, B. L. (1983). A new Porophyllum (Asteraceae: Tageteae) from south central Mexico. Phytologia 54 (2): $119-120$.

(1996). Porophyllum Guett. In: B. L. Turner, The Comps of Mexico: A systematic account of the family Asteraceae. Vol. 6. Tageteae and Anthemideae. Phytologia Mem. 10: 43 - 50.

Villaseñor, J. L. (2016). Checklist of the native vascular plants of Mexico. Catálogo de las plantas vasculares nativas de México. Revista Mex. Biodivers. 87: 559 902. [Porophyllum: p. 653].

\section{Publisher's Note}

Springer Nature remains neutral with regard to jurisdictional claims in published maps and institutional affiliations. 